\title{
"UKRAINIAN GRAMMAR" BY BORYS GRINCHENKO AND QUESTIONS OF THE NATIVE LANGUAGE SCHOOL (THE LAST THIRD OF THE XIX - THE BEGINNING OF THE XX CENTURY)
}

\author{
Olga Koliadenko \\ Postgraduate Student at the Department of Theory and History of Pedagogy, \\ Borys Grinchenko Kyiv University, Ukraine \\ e-mail: o.koliadenko@kubg.edu.ua, orcid.org/0000-0002-1232-0226
}

\section{Summary}

The article is devoted to reflecting the importance of a handwritten Ukrainian-language textbook for primary education, created by Boris Grinchenko, in order to form educated and cultured Ukrainians in their non-state life in the Russian Empire (last third of the XIX century the beginning of the XX century).

It is substantiated that B. Grinchenko (1863-1910) argued for the urgent need to teach Ukrainian children in their native language in a textbook that contains educational material close to them, because it corresponds to their mentality, nature and life experience. He used Ukrainian folklore in his textbook, which he began to collect in the villages at a young age: fables, stories, proverbs, riddles, jokes, proverbs, songs, fairy tales. The activist believed that didactic material, which is accessible in content and important for their nationally oriented upbringing, is rooted in the moral and spiritual traditions of the Ukrainian people, corresponds to the Ukrainian archetype, and therefore has a positive effect on the socially important formation of pupils' national identity. B. Grinchenko's didactic approaches to the implementation of nationally oriented education of peasants and their children by means of a Ukrainian-language textbook created on the basis of samples of folklore material are revealed.

Keywords: Boris Grinchenko, Ukrainian language, education, primer, necrology, ethnographic material, nation-building, national education.

DOI: https://doi.org/10.23856/4019

\section{Introduction}

The problem of creating school textbooks and popular science literature for the national school and education of Ukrainians in different historical periods was solved in different ways. As the outstanding Ukrainian philologist and literary critic I. Ogienko describes, «significant cultural centers with their schools, printing houses, scholars» already operated in the Ukrainian lands in the 16th - 17th centuries (Ohiienko, 1918: 37). However, under the pressure of the Russificationist educational policy of the Russian Empire, its fear of separatist movements in Ukraine, by the beginning of the XIX century Ukrainian schools in Ukraine already existed, and the Ukrainian language remained in use mainly by the rural population.

In the second half of the XIX century the Ukrainian language issue has become more acute. It should be noted that Borys Grinchenko (1863-1910) lived and worked in the most tragic times of Ukrainian history, when the Valuev-Emsk's bans on everything Ukrainian came into force in the Russian Empire. It was forbidden not only to write books in Ukrainian and import them from abroad, but also to make Ukrainian translations from other languages. The Ukrainian language was subject to constant restrictions and 
prohibitions, and total Russification led to the fact that the learning process and its means were exclusively Russian-speaking. The school in the Ukrainian lands was deprived of any national features. For the vast majority of Ukrainian pupils, Russian was not their native language, so both textbooks and teaching aids were incomprehensible to them, did not meet their natural and mental ideas and needs, and the learning process itself did not take into account cultural achievements and historical traditions of the Ukrainian people. Such education did not contribute to the development of the spiritual and intellectual potential of the Ukrainian nation. That is why the struggle of conscious Ukrainian public figures for the Ukrainian school and the creation of Ukrainian-language textbooks and books in various fields of knowledge that would provide nationally oriented content of education and basic education of the people, was one of the main tasks of nationally oriented public figures.

\section{Analysis of recent research and publications}

Many of his contemporaries studied the legacy of the outstanding Ukrainian educator Borys Grinchenko during his lifetime. The most important studies include the work of G. Sherstyuk "Boris Grinchenko and the Ukrainian school" (1910) (Sherstiuk, 1910), M. Kordub "National educational activities of B. Grinchenko" (1910) (Kordub, 1910), M. Plevako "Life and work of Boris Grinchenko" (1911) (Plevako, 1911), D. Pisochynets "Teaching of B. Grinchenko" (1911) (Pisochynets, [Tkachenko] 1911). In the 1920s, V. Durdukivsky devoted his analysis of B. Grinchenko's legacy to "Pedagogical work of B. Grinchenko" (1929) (Durdukivskyi, 1929).

Among the modern studies that have appeared in Ukraine since the 1980s, we can single out two monographs by A. Pohribny "Boris Grinchenko. Essay on life and work" (1988) (Pohribnyi, 1988) and "Boris Grinchenko in the literary movement of the last of the XIX century - the beginning of the XX century" (1990) (Pohribnyi, 1990), as well as the work of M. Verkalets "Pedagogical ideas of B.D. Grinchenko" (1990) (Verkalets, 1990), a study by A. Zhyvotenko-Piankiv "Pedagogical and educational work of B. Grinchenko" (1999) (Zhyvotenko-Piankiv, 1999). In some dissertations devoted to the figure and work of Borys Grinchenko (N. Zubkova "Library and archive of B.D. Grinchenko as a source on the history of public education in Ukraine at the end of the XIX century - the beginning of the XX century" (1994) (Zubkova, 1994), M. Malysh "Book publishing activity of B. Grinchenko" (1994) (Malysh, 1994), M. Odintsova "Manuscripts and magazines of Borys Grinchenko: editorial and publishing aspect" (2014) (Odintsova, 2014)) there are only episodic mentions of Borys Grinchenko's textbooks.

Among the numerous historical, philological, literary, cultural dissertations completed within the period of 1990-2019, only two dissertations concerned the field of pedagogy - O. Nezhyvyi "Pedagogical Legacy of Borys Grinchenko" (1995) (Nezhyvyi, 1994) and K. Tymoshenko "Educational pedagogical activity of B. D. Grinchenko in Slobozhanshchyna" (2008) (Tymoshenko, 2008). These works analyze and highlight the multifaceted activities of B. Grinchenko, aimed at the development of the national idea, native language education as an integral part of national culture. However, their authors purposefully did not consider his handwritten textbooks in didactic and pedagogical aspects. Prior to that, these researchers were not able to use a significant part of the original sources of the great legacy of the educator, waiting for the study in the archives and bookstores, so there is a need to analyze new sources discovered during the 2000s, and thus supplement and clarify predecessors. 
The purpose of the article is to analyze the Ukrainian-language textbook created by B. Grinchenko for primary education in connection with the coverage of its role in the educational revival of Ukraine at the end of the XIX century - the beginning of the XX century.

\section{Research results}

Having formed as a conscious, Ukrainian-oriented personality at a young age, Borys Grinchenko was well aware that the only means of developing national self-awareness and spreading literacy among the Ukrainian population was a native language book. According to him, it was the most effective means of moral and ethical, mental development of a pupil, a person. The creation of textbooks and books in the Ukrainian language and with the use of the national component became the leading task of the educator. And the solution of this problem became a separate direction of his scientific, pedagogical and publishing activity.

In love with his native people, its original culture, Borys Dmytrovych suffered from the fact that as a teacher he was forced to implement the Russification policy of the tsarist government - to teach rural Ukrainian children in Russian. Every day, faced with the dubious consequences of such education in the language that was incomprehensible to children, the young teacher, working in the village Triichate in Kharkiv region, decided in 1882 to teach them Ukrainian literacy secretly. To facilitate learning, Borys Grinchenko wrote short texts in block letters (a kind of primer) (Durdukivskyi, 1929: 59). Then, in 1888, reworking and perfecting his first book-attempt, continuing its development in the spirit of the best traditions of Ukrainian pedagogical thought in writing primers, creatively comprehending what was done by predecessors, in particular "Southern Russian Primer" (1861) T. Shevchenko (Shevchenko, 1861), "Grammar" (1857) P. Kulish (Kulish, 1857), he compiles and paints textbooks for primary education, among which - a handwritten native primer "Ukrainian Grammar for the Science of Reading and Writing” (IR NBUV (Instytut rukopysu Natsionalnoi biblioteky Ukrainy imeni V. I. Vernadskoho) MI NLUV (Manuscript Institute of National Library of Ukraine named after V.I. Vernadsky), f. I, od. zb. 31536). In this work he used his own practical teaching experience.

The purpose of the grammar is to assist Ukrainian children in learning so that they can easily, without much effort, learn to read and write, encourage self-employment, and facilitate the work of teachers. According to the same book, the activist taught his daughter Nastia, as well as peasants in the village Oleksiivtsi in Katerynoslav region, "wishing that the science would appeal to them in their native language" (Grinchenko, 1907: 61).

Although B. Grinchenko wrote the primer in 1888, it was first published only in 1907 in Kyiv (Grinchenko, 1907), when the Russian Empire adopted a constitutional manifesto (Manifest "Ob usovershenstvovanii Gosudarstvennogo poryadka" (17 oktyabrya 1905 g.). 26803. Polnoe sobranie zakonov Rossijskoj Imperii, 1905) and approved the "Temporary Rules on the Press" (1905) (Imennoj Vysochajshij ukaz, dannyj Senatu "O vremennyh pravilah o povremennyh izdaniyah" (24 noyabrya 1905 g.). 26962. Polnoe sobranie zakonov Rossijskoj Imperii, 1905), which lifted censorship and ban on the Ukrainian press, and Ukrainians hoped to open Ukrainian schools.

Another reason for Borys Grinchenko's creation of a Ukrainian-language textbook was his belief in the idea that the Ukrainian language is a powerful unifying factor capable of uniting the nation. To confirm the veracity of this idea, we give an excerpt from such a document of that time (quoted by M. Tymoshyk (Tymoshyk, 2007: 242-243)), as a circular prepared by the Imperial Main Directorate for the Press, which explains the categorical reluctance of the tsarist government to spread in the empire Ukrainian language and literature and first of all - in 
a printed form: “...nothing unites people politically as much as the unity of language and literature, and conversely, nothing separates them more than the difference between language and writing. To allow the creation of a special folk literature in the Ukrainian dialect could mean to lay a solid foundation for the development of the belief in possibility of future ... alienation of Ukraine from Russia".

The language, the printed word united people, lifted them from their knees, encouraged them to think and self-identify, transformed them from "Malorosy", "Khokhly" into Ukrainians. As I. Ogienko emphasized: "Language is the soul of every nationality, its sanctity, its most valuable treasure; and as long as the language lives, the people will live as a nationality; there will be no language - there will be no nationality: it will be completely scattered among the stronger people" (Ohiienko, 1918: 239-240).

So, that's why B. Grinchenko wrote a primer for rural students by hand, in large block letters, in order to teach them literacy more effectively in their native language. "Ukrainian Grammar for the Science of Reading and Writing" fulfilled the "mission" of educating the Ukrainian population. "Teach children to read and write: everyone needs literacy, it shows the world to life", - one of his pupils M. Pozniakova recalled the words of B. Grinchenko (Pozniakova, 1910: 178).

B. Grinchenko's grammar consists of two parts: a primer and a post-primer, entitled "Reading after the Alphabet". At the end of the book there are copy-books and a methodical article "To Teachers".

The primer part of the grammar is divided into 29 paragraphs - according to the number of letters of the alphabet. Each paragraph contains a picture of the subject and a signature-explanation to it, that is, a word with a new letter, then separate words, sentences, and finally - short stories. The author explained that he tried to arrange the letters in such an order that at first there were easier to pronounce sounds, and that there was enough material to read (Grinchenko, 1907: 62). At the end of each paragraph, starting with the 11th one, there are separate written exercises of grammatical nature, advice to teachers (nowadays - methodical recommendations) on how to organize the performance of such exercises by pupils.

There are exercises in the book and lexical material of family and household nature, which is well known to young rural pupils. The author also took into account the patriotic aspect of education, in particular, it states that "Our dear Ukraine is our native land. Ukrainian language is our native language" (Grinchenko, 1907: 36).

As an outstanding Ukrainian ethnographer, Borys Grinchenko already had a rich and interesting folklore material (fables, stories, poems, proverbs, riddles, jokes, proverbs, songs, fairy tales), which contained centuries of experience of the Ukrainian people and had (and has) rich moral and instructive content. The author successfully used it in the post-letter, or, so to speak, the textbook part of "Grammar", which made its content interesting and accessible to children. For example, the book contains the following proverbs-maxims: "Get used to work from a young age and you will never know hunger in an old age"; "Do not rejoice at another's misfortune"; "Do more, talk less"; "You will pass through the world with a lie, but you will not return"; "Better not to promise than not to keep your word" (Grinchenko, 1907: 38) and others. In our opinion, this B. Grinchenko's didactic approach promoted learning on the basis of arousal of interest, interest in children, and thus made learning more productive.

Special attention should be paid to the small texts for reading placed in the primer part, as well as in the post-primer "Reading after the Alphabet". The author explained that he sought to «teach only fully understandable material to children, moving from easy to difficult», as well as to make it interesting in content (Grinchenko, 1907: 63). Therefore, B. Grinchenko wrote 
several short stories based on folk plots especially for grammar. This material was a subject to pedagogical and educational expediency, aimed at forming in children positive moral qualities - sensitivity, honesty, friendship, respect to work and study.

We also emphasize that B. Grinchenko acquaints children with prominent figures of Ukrainian literature. The textbook contains poems by L. Glibov, P. Kulish, T. Shevchenko, as well as Grinchenko's own ones.

In his primer, B. Grinchenko proposed examples of italics in lowercase and uppercase letters, as well as words and expressions with them. The analysis of the text proves that the exercises for writing are presented in a logical sequence, which contributed to the development of skills of correct calligraphic writing (Grinchenko, 1907: 53-60).

In his didactic advice, B. Grinchenko advised teachers to set aside up to 14 days for the pre-literacy period before starting to learn letters, and he considered analytical-synthetic exercises and writing elementary lowercase letters to be the main content of teaching in this period. For all lessons, he chose the words mostly on the principle of similarity, i.e. they differed in a letter or syllable. He also paid some attention to the problem of the child's inability to merge one sound with another, which interferes with good reading. To get rid of this situation, he advised to teach children to simultaneously merge the sound with others, memorizing the appropriate letter and the form of its spelling (Grinchenko, 1907: 61-62).

Regarding the alphabet presented in "Ukrainian Grammar", B. Grinchenko remarked in the methodical letter "To Teachers": "I took the full Ukrainian alphabet of 33 letters, that is: all the letters that are used in the words of the Ukrainian language, without throwing out the letter I, which is impossible to do without" (Grinchenko, 1907: 64).

\section{Conclusions}

The grammar analysis gives the grounds to claim that with his life, activity, creative work B. Grinchenko proved the decisive role of purposefulness, persistence and diligence in achieving the chosen goal. He emphasized the importance of everyone's actions for the common cause. He was a humanist-patriot, believed in people and children, their ability to become highly educated and cultured citizens.

We believe that the main achievement of the textbook "Grammar for the Science of Reading and Writing" is that B. Grinchenko created a qualitatively new Ukrainian-language primer-reader in terrible, difficult times of national oppression, without fear of punishment for violating royal decrees. And not only created, but also practically implemented it in teaching children their native language.

It is also fundamentally important that Ukrainian folklore became the dominant factor in the selection of didactic material for grammar, which made it possible to teach children their native language in its most perfect and beautiful manifestation - in various types of oral folk art. The author chose the sound analytical-synthetic method of teaching literacy, developed an appropriate method of teaching writing, which corresponded to the didactic principles of naturalness, accessibility, national character.

B. Grinchenko's textbook is a manual on the Ukrainian language, its spelling, as well as didactic and methodical recommendations for teachers. It has taken its rightful place in the history of national education in Ukraine and has become a valuable contribution to the development of methods of teaching reading and writing in the Ukrainian language. It became an invaluable experience of Ukrainian primary school pedagogy in the last third of the XIX century. 


\section{References}

Verkalets, M. (1990). Pedahohichni idei B.D. Hrinchenka [Pedagogical ideas of B. D. Grinchenko]. Kyiv, Ukraine: Znannia. [in Ukrainian].

Grinchenko, B. (1907). Ukrainska hramatyka do nauky chytannia y pysannia [Ukrainian grammar for the science of reading and writing]. Kyiv, Russian Empire: Vik. [in Ukrainian].

Durdukivskyi, V. (1929). Pedahohichna diialnist B. Hrinchenka. Vseukrainska akademiia nauk. Istoryko-filolohichnyi viddil. № 97: Pratsi naukovo-pedahohichnoi komisii [Pedagogical activity of B. Grinchenko. All-Ukrainian Academy of Sciences. Historical and Philological Department № 97: Proceedings of the scientific and pedagogical commission]. (Vol. I). Kyiv, USSR. [in Ukrainian].

Zhyvotenko-Piankiv, A. (1999). Pedahohichno-prosvitnytska pratsia Borysa Hrinchenka [Pedagogical and educational work of Borys Grinchenko]. Kyiv, Ukraine: Vydavnychyi tsentr «Prosvita». [in Ukrainian].

Zubkova, N. (1994). Biblioteka i arkhiv B.D. Hrinchenka yak dzherelo z istorii narodnoi prosvity Ukrainy kin. XIX-poch. XX st. [Library and archive of B.D. Grinchenko as a source on the history of public education in Ukraine late XIX-early XX centuries]. Extended abstract of candidate's thesis. Kyiv, Ukraine. [in Ukrainian].

Imennoj Vysochajshij ukaz, dannyj Senatu «O vremennyh pravilah o povremennyh izdaniyah» (24 noyabrya 1905 g.). 26962. Polnoe sobranie zakonov Rossijskoj Imperii [A personalized Imperial decree given to the Senate «On provisional rules for time-based publications» (November 24, 1905). 26962. Complete collection of laws of the Russian Empire]: $v 33 t$. 3-e sobr. 1905, T. XXV, Otdelenie 1: Ot № 25605-27172. 1908. 837-840. Sankt-Peterburg, Russian Empire. [in Russian].

IR NBUV (Instytut rukopysu Natsionalnoi biblioteky Ukrainy imeni V. I. Vernadskoho) - MI NLUV (Manuscript Institute of National Library of Ukraine named after V.I. Vernadsky), f. I, od. zb. 31536. [in Ukrainian].

Kordub, M. (1910). Narodnoprosvitnia diialnist Borysa Hrinchenka. Na mohylu Borysa Hrinchenka. Try promovy [Public educational activity of Borys Grinchenko. To the grave of Borys Grinchenko. Three speeches]. Chernivtsi, Galician. [in Ukrainian].

Kulish, P. (1857). Hramatka [Necrology]. Sankt-Peterburh, Russian Empire: Typohrafiia P.A. Kulysha. [in Ukrainian].

Malysh, M. (1994). Knyhovydavnycha diialnist B. Hrinchenka [Book publishing activity of B. Grinchenko]. Extended abstract of candidate's thesis. Kyiv, Ukraine. [in Ukrainian].

Manifest "Ob usovershenstvovanii Gosudarstvennogo poryadka» (17 oktyabrya 1905 g.). 26803. Polnoe sobranie zakonov Rossijskoj Imperii [Manifesto «On the improvement of the state order» (October 17, 1905). 26803 Complete collection of laws of the Russian Empire]: v 33 t. 3-e sobr. 1905, T. XXV, Otdelenie 1: Ot № 25605-27172. 1908. 754-755. Sankt-Peterburg, Russian Empire. [in Russian].

Nezhyvyi, O. (1994). Pedahohichna spadshchyna Borysa Hrinchenka [Pedagogical legacy of Borys Grinchenko]. Extended abstract of candidate's thesis. Kharkiv, Ukraine. [in Ukrainian]. Ohiienko, I. (1918). Ukrainska kultura: korotka istoriia kultur. zhyttia ukrainskoho naroda; kurs, chytanyi v ukr. nar. un-ti [History of culture: a brief history of cultures]. Kyiv: Vyd-vo Knyharni Ye. Cherepovskoho. [in Ukrainian].

Odintsova, M. (2014). Rukopysni knyhy i zhurnaly Borysa Hrinchenka: redaktsiino-vydavnychyi aspekt [Manuscripts and magazines of Borys Grinchenko: editorial and publishing aspect]. Extended abstract of candidate's thesis. Kyiv, Ukraine. [in Ukrainian]. 
Pisochynets, D. [Tkachenko, D.] (1911). Uchyteliuvannia Borysa Hrinchenka [Borys Grinchenko's teaching]. Svitlo - Light, 5, 31-46. [in Ukrainian].

Plevako, M. (1911). Zhyttia ta pratsia Borysa Hrinchenka [Life and work of Borys Grinchenko]. Kharkiv, Russian Empire: Vyd-vo im. Borysa Hrinchenka. [in Ukrainian].

Pohribnyi, A. (1990). Borys Grinchenko v literaturnomu rusi kintsia KhIX-KhKh st. Pytannia ideino-estetychnoi evoliutsii [Borys Grinchenko in the literary movement of the late XIX-XXcenturies. Questions of ideological and aesthetic evolution]. Kyiv, USSR: Lybid. [in Ukrainian]. Pohribnyi, A. (1988). Borys Grinchenko. Narys zhyttia i tvorchosti [Boris Grinchenko. Essay on life and work]. Kyiv, USSR: Dnipro. [in Ukrainian].

Pozniakova, M. (1910). Spomynky. Nad mohyloiu Borysa Hrinchenka: Avtobiohrafiia, pokhoron, spomyny, statti [Memories. Above the grave of Borys Grinchenko: Autobiography, funeral, memoirs, articles]. Kyiv, Russian Empire: Vik. [in Ukrainian].

Tymoshenko, K. (2008). Prosvitnytsko-pedahohichna diialnist B.D. Hrinchenka na Slobozhanshchyni [Educational and pedagogical activity of B. D. Grinchenko in Slobozhanshchina]. Extended abstract of candidate's thesis. Kharkiv, Ukraine. [in Ukrainian].

Tymoshyk, M. (2007). Istoriia vydavnychoi spravy [History of publishing]: pidruchnyk. 2-he vyd., vypravlene. Kyiv: Nasha kultura i nauka. [in Ukrainian].

Shevchenko, T. (1861). Bukvar yuzhnorusskij [South Russian primer]. Sankt-Peterburg: V pechatni Gogenfeldena i Ko. [in Ukrainian].

Sherstiuk, H. (1910). Borys Grinchenko $i$ vkrainska shkola [Borys Grinchenko and the Ukrainian school]. Svitlo - Light, 1, 9-14. [in Ukrainian]. 